\title{
Analysis of Weather Forecasting Techniques
}

\author{
Swati Pandey ${ }^{1}$, Shruti Sharma ${ }^{1}$, Shubham Kumar ${ }^{1}$, Kanchan Bhatt ${ }^{1}$, Dr. Rakesh Kumar Arora ${ }^{2}$ \\ ${ }^{1}$ Department of Computer Science and Engineering, Krishna Engineering College, Ghaziabad, India \\ ${ }^{2}$ Professor, Department of Computer Science and Engineering, Krishna Engineering College Ghaziabad, India
}

Article Info

Volume 7, Issue 4

Page Number: 80-85

Publication Issue :

July-August-2021

\section{Article History}

Accepted : 02 July 2021

Published : 09 July 2021

\begin{abstract}
Weather forecasting is one of the important science application in our daily planning activities. This application has played a significant role to humans from a long time. Every human relied on their philosophical experience and other weather phenomenon to predict the weather and infer what was coming their way. This was the knowledge gathered over many years observations and has been passed from one generation to another. To predict the future's weather condition, the variation in the conditions in past year must be utilized. The probability that the weather condition of the day in consideration will match the same day in previous year is very less. But the probability that it will match within the spam of adjacent fortnight of previous year is very high. In this paper, we analyse the use of various data mining techniques in forecasting maximum temperature, rainfall and wind speed.
\end{abstract}

Keywords: Forecasting, Data Mining Techniques, Probability, Prediction

\section{INTRODUCTION}

We are always with or around a weather forecast; we always carry it with us and never want to be away from it. On average, we might encounter this about four-five times a day: news bulletin, newspaper, tweets, conversation, TV, mobile apps, internet, etc. weather forecasting is one of the most prominent topics that has influenced people's lives and activities over a long time. It is a kind of scientific activity, contributing to the social and economic welfare in many sections of the world. People can also know and be aware of atmospheric changes through variables such as temperature, wind speed and direction. Variations in these parameters describe weather the state of the atmosphere at a particular time.

Weather forecasting has become an important field of research and has always been done since the ancient time. There are a variety of end users to weather forecasts. Weather warnings are important forecasts because they are used to protect life and property. Forecasts based on temperature and precipitation are important to agriculture, Weather forecasts are also used by utility companies to estimate demand over coming days. It provides critical information about future weather, some of them are climate monitoring, 
planning in energy industry. Accurate prediction of weather conditions is a difficult task due to the dynamic nature of atmosphere. Out of those variables, one found that the most significant are being selected to be involved in the process of prediction. The variables and their ranges always vary from place to place. The weather condition of any day has some relationship with the weather condition existed in the same tenure of precious year and previous work.

\section{LITERATURE SURVEY}

On a worldwide scale giant numbers of makes an attempt have been created by completely different researchers to forecast Weather accurately victimization numerous techniques however due to nonlinear nature of Weather prediction accuracy obtained by these techniques remains below the satisfactory level.

Sarma, Konwar and Das shows that Artificial Neural Network (ANN) can also combined with different ways. A neural network model for rainfall retrieval over ocean remotely detected microwave (MW) brightness temperature (BT). They projected soft computing approach for rainfall prate over ocean victimization on-line feature selection, clustering, and hybrid neural network

F. Mekanik and M. A. Imteaz found that downfall is also affected by the key modes of complicatedclimate variables. Few makes an attempt area unit created to establish the combined result of these indices on downfall therefore on develop a much better understanding in forecast system. Artificial neural network area unit extensively

used in recently numerous facet of science and engineering because of its handiness to model both linear and system while not the need to assumption create assumption as area unit implicit in a lot of ancient applied math approaches.

Vamsithar , Rao and Satayapati use the back propagation neural network model for predicting the downfall supported humidness, dew point and pressure among the country Asian country . TwoThird of the information was used for coaching and common fraction for testing. the quantity of coaching job patterns is 250 coaching and testing patterns are120. among the coaching they obtained $99.79 \%$ of accuracy and in Testing $94.28 \%$ of accuracy.

This result will predict the downfall for the future. For downfall prediction, Artificial Neural Network was applied and also the downfall was predicted in India. in keeping with the result back propagation neural network were acceptably and may be use for predicting the rainfall. therefore, by exploitation this technique of prediction we can realize the quantity of downfall within the region by exploitation the attributes like humidness, dew point and pressure. Luk, Ball and Sharma delineated that thanks to complexity of the region processes by which downfall is generated and also the lack of available of information on the mandatory temporal and spatial scales, it's not possible usually to forecast downfall employing a physically based mostly method model.

TV Rajinikanth et al. has projected a methodology for analyzing the scientific discipline information that is noticeably suite especially to the Indian weather environments exploitation information mining techniques. The connected information is grouped basing on $\mathrm{k}$ suggests that algorithmic rule ,a decision tree is employed for predicting the observations. 
III. IMPLEMENTATION

\begin{tabular}{|c|c|c|c|c|c|}
\hline S.NO & $\begin{array}{c}\text { Research } \\
\text { Paper }\end{array}$ & Author & $\begin{array}{l}\text { Major } \\
\text { Focus }\end{array}$ & Advantages & Disadvantages \\
\hline 1 & $\begin{array}{l}\text { The Weather } \\
\text { Forecast using } \\
\text { Data Mining } \\
\text { Research based } \\
\text { on Cloud } \\
\text { Computing }\end{array}$ & $\begin{array}{l}\text { ZhanJie Wang } \\
\text { and A. B. M. } \\
\text { Mazharul Mujib }\end{array}$ & $\begin{array}{l}\text { Paper proposes a modern } \\
\text { method to develop a } \\
\text { service oriented } \\
\text { architecture for the } \\
\text { weather information } \\
\text { systems which forecast } \\
\text { weather using these data } \\
\text { mining techniques. }\end{array}$ & $\begin{array}{l}\text { The weather } \\
\text { forecasting } \\
\text { algorithm is } \\
\text { used to } \\
\text { predict } \\
\text { weather for } \\
\text { several days }\end{array}$ & $\begin{array}{l}\text { Wind speed } \\
\text { and } \\
\text { temperature } \\
\text { value displayed } \\
\text { the simulation } \\
\text { result, but it } \\
\text { can be more } \\
\text { exact while } \\
\text { using more } \\
\text { data inputs }\end{array}$ \\
\hline 2 & $\begin{array}{l}\text { An efficient } \\
\text { weather } \\
\text { forecasting } \\
\text { system using } \\
\text { artificial neural } \\
\text { network }\end{array}$ & $\begin{array}{l}\text { Dr. S. Santhosh } \\
\text { Baboo and } \\
\text { I.Kadar } \\
\text { Shereef }\end{array}$ & $\begin{array}{l}\text { The approach is to predict } \\
\text { the temperature by } \\
\text { determining the non- } \\
\text { linear relationship that } \\
\text { exists between the } \\
\text { historical data supplied to } \\
\text { the system }\end{array}$ & $\begin{array}{l}\text { The } \\
\text { application } \\
\text { is able to } \\
\text { predict the } \\
\text { temperature } \\
\text { in present } \\
\text { and in future }\end{array}$ & $\begin{array}{l}\text { The } \\
\text { application is } \\
\text { good in } \\
\text { predicting the } \\
\text { temperature } \\
\text { only not the } \\
\text { others } \\
\text { parameter }\end{array}$ \\
\hline 3 & $\begin{array}{l}\text { Research on } \\
\text { Real-Time Local } \\
\text { Rainfall } \\
\text { Prediction } \\
\text { Based on MEMS } \\
\text { Sensors }\end{array}$ & $\begin{array}{l}\text { Zeyi Chao, } \\
\text { Fangling Pu, } \\
\text { Yuke Yin, } \\
\text { Bin Han, Xiaoling } \\
\text { Chen }\end{array}$ & $\begin{array}{l}\text { The developed automatic } \\
\text { meteorological stations } \\
\text { based on MEMS sensors } \\
\text { can provide high time } \\
\text { resolution and spatial } \\
\text { resolution in monitoring } \\
\text { Rainfall }\end{array}$ & $\begin{array}{l}\text { The } \\
\text { application } \\
\text { is capable of } \\
\text { predicting } \\
\text { Rainfall for } \\
\text { particular } \\
\text { area }\end{array}$ & $\begin{array}{l}\text { MEMS sensors } \\
\text { suffer from } \\
\text { stochastic error } \\
\text { which can lead } \\
\text { to inaccurate } \\
\text { prediction }\end{array}$ \\
\hline 4 & $\begin{array}{l}\text { Application of } \\
\text { the deep } \\
\text { learning for } \\
\text { prediction of } \\
\text { the Rainfall }\end{array}$ & $\begin{array}{l}\text { Meng-Hua Yen, } \\
\text { Ding-Wei liu, Yi- } \\
\text { Chia Hsin, Chu- } \\
\text { En Lin }\end{array}$ & $\begin{array}{l}\text { The purpose is to develop } \\
\text { a forecasting model of } \\
\text { Rainfall using RC to } \\
\text { investigate possible } \\
\text { factors in governing } \\
\text { Rainfall Forecast }\end{array}$ & $\begin{array}{l}\text { The } \\
\text { application } \\
\text { is able to } \\
\text { predict the } \\
\text { rainfall }\end{array}$ & $\begin{array}{l}\text { Some of the } \\
\text { parameter lead } \\
\text { to irrelevant } \\
\text { prediction }\end{array}$ \\
\hline
\end{tabular}


Swati Pandey et al Int. J. Sci. Res. Comput. Sci. Eng. Inf. Technol, July-August-2021, 7 (4) : 80-85

\begin{tabular}{|c|c|c|c|c|c|}
\hline 5 & $\begin{array}{l}\text { Smart Weather } \\
\text { Forecasting } \\
\text { using Machine } \\
\text { Learning }\end{array}$ & $\begin{array}{l}\text { A H M Jakaria, } \\
\text { Md Mosharaf } \\
\text { Hossain, } \\
\text { Mohmmad } \\
\text { Ashiqur Rahman }\end{array}$ & $\begin{array}{l}\text { It Present a weather } \\
\text { prediction technique that } \\
\text { utilizes historical data } \\
\text { from multiple weather } \\
\text { stations to train simple } \\
\text { machine learning models, } \\
\text { which can provide usable } \\
\text { forecasts about certain } \\
\text { weather conditions for } \\
\text { the near future within a } \\
\text { very short period of time }\end{array}$ & $\begin{array}{l}\text { The } \\
\text { application } \\
\text { is able to do } \\
\text { weather } \\
\text { forecast } \\
\text { using } \\
\text { machine } \\
\text { learning } \\
\text { techniques }\end{array}$ & $\begin{array}{l}\text { The } \\
\text { application } \\
\text { Is able to } \\
\text { predict } \\
\text { weather for a } \\
\text { particular area }\end{array}$ \\
\hline 6 & $\begin{array}{l}\text { Weather } \\
\text { forecasting } \\
\text { model using } \\
\text { Artificial Neural } \\
\text { Network }\end{array}$ & $\begin{array}{l}\text { Kumar Abhishek, } \\
\text { M.P. Singh, } \\
\text { Saswata Ghosh, } \\
\text { Abhishek Ananad }\end{array}$ & $\begin{array}{l}\text { The paper examines the } \\
\text { applicability of ANN } \\
\text { approach by developing } \\
\text { effective and reliable } \\
\text { nonlinear predictive } \\
\text { models for weather } \\
\text { analysis also compare and } \\
\text { evaluate the performance } \\
\text { of the developed models } \\
\text { using different transfer } \\
\text { functions, hidden layers } \\
\text { and neurons to forecast } \\
\text { maximum, temperature } \\
\text { for } 365 \text { days of the year. }\end{array}$ & $\begin{array}{l}\text { The } \\
\text { application } \\
\text { is good in } \\
\text { predicting } \\
\text { the } \\
\text { temperature. }\end{array}$ & $\begin{array}{l}\text { The } \\
\text { application is } \\
\text { not be able to } \\
\text { predict others } \\
\text { factors such as } \\
\text { Rainfall. }\end{array}$ \\
\hline 7 & $\begin{array}{l}\text { A Machine } \\
\text { learning } \\
\text { approach for } \\
\text { weather } \\
\text { forecasting }\end{array}$ & $\begin{array}{l}\text { Bin Wang, Jie Lu, } \\
\text { Zheng Yan, } \\
\text { Huaishao Luo }\end{array}$ & $\begin{array}{l}\text { This paper focuses on } \\
\text { designing a data-driven } \\
\text { method augmented by an } \\
\text { effective information } \\
\text { fusion mechanism to } \\
\text { learn from historical data } \\
\text { that incorporates prior } \\
\text { knowledge from NWP. }\end{array}$ & $\begin{array}{l}\text { The } \\
\text { application } \\
\text { is based on } \\
\text { the } \\
\text { numerical } \\
\text { solution of } \\
\text { atmospheric } \\
\text { hydro } \\
\text { thermo } \\
\text { dynamic } \\
\text { equations } \\
\text { and is able } \\
\text { to obtain } \\
\text { high } \\
\text { prediction } \\
\text { accuracy. }\end{array}$ & $\begin{array}{l}\text { The } \\
\text { application } \\
\text { might not be } \\
\text { reliable due to } \\
\text { the instability } \\
\text { of these } \\
\text { differential } \\
\text { equations }\end{array}$ \\
\hline
\end{tabular}


Swati Pandey et al Int. J. Sci. Res. Comput. Sci. Eng. Inf. Technol, July-August-2021, 7 (4) : 80-85

\begin{tabular}{|c|c|c|c|c|c|}
\hline 8 & $\begin{array}{l}\text { An integrated } \\
\text { approach for } \\
\text { analyzing and } \\
\text { measuring } \\
\text { weather data }\end{array}$ & $\begin{array}{l}\text { Munmun Biswas, } \\
\text { Tanni Dhoom, } \\
\text { Sayantanu Barua }\end{array}$ & $\begin{array}{l}\text { This project aims to } \\
\text { estimate the weather by } \\
\text { utilizing predictive } \\
\text { analysis. For this reason, } \\
\text { analysis of various data } \\
\text { mining procedures is } \\
\text { needed before apply. This } \\
\text { system is a web } \\
\text { application with effective } \\
\text { graphical User Interface. } \\
\text { User will login to the } \\
\text { system utilizing his user } \\
\text { ID and password. User } \\
\text { will enter some } \\
\text { information such as } \\
\text { current outlook, } \\
\text { temperature, humidity } \\
\text { and wind condition. This } \\
\text { system will take this } \\
\text { parameter and predict } \\
\text { weather after analyzing } \\
\text { the input information } \\
\text { with the information in } \\
\text { database. }\end{array}$ & $\begin{array}{l}\text { The } \\
\text { application } \\
\text { is able to } \\
\text { predict } \\
\text { current } \\
\text { weather } \\
\text { atmosphere. }\end{array}$ & $\begin{array}{l}\text { The system is } \\
\text { not capable of } \\
\text { predicting } \\
\text { weather more } \\
\text { than one day }\end{array}$ \\
\hline
\end{tabular}

IV. RESULT

Weather forecasting is the endeavour to foresee the climate conditions at some future time. Accuracy of weather shown in forecast reports is very necessary. This paper reviews number of varied techniques for predicting daily meteorology. The comparison uses different parameters to forecast the daily weather in terms of rainfall, humidity, temperature, cloud condition, and weather of the day.

The prime contribution of this paper is to compare the present weather forecasting model and to choose the precise model based on their analytical ability.

\section{CONCLUSION}

This paper presented an overview of weather forecasting techniques with time series data describing the main contributions in this field. Papers were reviewed to emphasize the diversity of forecasting methods and the time-scales of forecasting methods. It is difficult to evaluate the performance of various methods, as the existing applications were in different time-scale and different way. This review is very useful, since it brings a better understanding of the field of analysis, and this is an important role in this paper. From the review it can be concluded that this field invites a great deal of interest by researchers. However, 
numerous research issues remain unexplored. One of the idea that were identified during this research is related with the combined use of various climatic issues.

\section{REFERENCES}

[1]. Swati Pandey, Shruti Sharma, Shubham Kumar, Kanchan Bhatt, Dr Rakesh Kumar Arora, "Weather Forecast through Data Mining" International Journal of Scientific Research in Computer Science, Engineering and Information and Technology, Volume 7, Issue 3, Page Number: 90-95

[2]. Lorenzo Luini, Carlo Capsoni, "A Unified Model for the Prediction of Spatial and Temporal Rainfall Rate Statistics" IEEE trans 2013.

[3]. State wise Rainfall Statistics in India and monthly Rainfall growth details figures from www.indiaset.com

[4]. Kumar Abhishek, M.P.Singh , Saswata Ghosh , Abhishek Anand "Weather Forecasting model using Artificial Neural Network" - Procedia Technology 2018

[5]. Mohamed Akram Zaytar, Chaker El Amrani “ Sequence to Sequence Weather Forecasting With Long Short Term Memory Recurrent Neural Networks" - International Journal of Computer Applications (0975-8887) Volume143 - No.11, June 2016.

[6]. Liu, J.N.K., Lee, R.S.T. , "Rainfall Forecasting from Multiple Point Source Using Neural Networks", IEEE Int'l. Conf. Systems 2019.

[7]. Likas, Nikos Vlassis, Jakob J. Verbeek, "The global k-means clustering algorithm", Pattern Recognition, The Journal of the Pattern Recognition Society, March 2002

[8]. Fahad Sheikh ,S. Karthick, "Analysis of Data Mining Techniques for Weather Prediction", Indian Journal of Science and Technology , 2016.

[9]. Rakesh Kumar Arora, Dharmendra Badal, "Evaluating student performance using $\mathrm{k}$ means clustering", International Journal of Computer Science and Technology, 2013.

[10].Prashant Biradar, Sarfraz Ansari, Yashavant Paradkar and Savita Lohiya, "Weather Prediction Using Data Mining", International Journal of engineering research and development 2017.

[11].Anagha Byakude Aishwarya Dhore, Bhagyashri Sonar and Mansi Waste, "Weather prediction using the data mining Technique”, IEEE 2016.

[12].Deepti Gupta and Udayan Ghose, "A Comparative Study of Classification Algorithms for Forecasting Rainfall", IEEE Publications 2015.

[13].Rakesh Kumar Arora, Dharmendra Badal, "Subject Distribution using Data Mining", International Journal of Research in Engineering and Technology, Volume 2,Issue 12,2013.

[14].Jiawei Han and Micheline Kamber (2006), Data Mining Concepts and Techniques, published by Morgan Kauffman, 2nd ed.

[15].Rakesh Kumar Arora, Dharmendra Badal, "Mining Association Rules to improve Academic Performance", International Journal of Computer Science and Mobile Computing, Volume 3, Issue 1, 2014

[16].India Statistical : https://www.indiastat.com/

[17]. India Meteorological Department https://mausam.imd.gov.in

\section{Cite this article as :}

Swati Pandey, Shruti Sharma, Shubham Kumar, Kanchan Bhatt, Dr. Rakesh Kumar Arora, "Analysis of Weather Forecasting Techniques", International Journal of Scientific Research in Computer Science, Engineering and Information Technology (IJSRCSEIT), ISSN : 2456-3307, Volume 7 Issue 4, pp. 80-85, July-August 2021. Available at doi : https://doi.org/10.32628/CSEIT217421 Journal URL : https://ijsrcseit.com/CSEIT217421 